\title{
Wat is die kerk?
}

\author{
'n Belydenis - óf 'n belydende Kerk
}

JOH DREYER

Met die Algemene Kerkvergadering gedurende Mei 1979 is die Kerkwet met sy Bepalings hersien en herskrywe. Met dié geleentheid is ook Artikel I wat oor die Kerk handel, enigsins gewysig; duideliker en juister omskrywe. Dit lui nou soos volg:

"Die Nederduitsch Hervormde Kerk van Afrika is ooreenkomstig sy belydenis 'n Christusbelydende volkskerk en as sodanig openbaring van die een heilige, algemene Christelike Kerk. Die Kerk grond hom op die Bybel as die Woord van God. Sy belydenis word uitgedruk in die formuliere van eenheid, naamlik die Nederlandse Geloofsbelydenis, die Heidelbergse Kategismus en die Dordtse Leerreëls in 1618 en 1619 in Dordtrecht vasgestel."

Die Kerk spreek hom hier uit as 'n Christusbelydende Kerk. Met hierdie stelling sê die Kerk dus wat hy eintlik is. En met hierdie stelling sê die Kerk terselfdertyd wat sy eintlike taak en roeping is, naamlik om Christus te bely.

Teenoor hierdie duidelike stelling is daar ander kerke wat dit enigsins anders stel, naamlik dat hulle 'n belydeniskerk is. Op hierdie verskilpunt is daar op die Algemene Kerkvergadering gewys. Ons beskou dit nogal as 'n interessante en belangrike punt van diskussie.

Dr Abr Kuyper, die groot organiseerder en besielende leier met die Doleansie, die tweede afskeidingsbeweging uit die Hervormde Kerk van Nederland gedurende die tagtigerjare van die vorige eeu, was die man wat groot klem gelê het op die belydenis en dit sterk na vore gebring het in die kerklike stryd. Dit het onder sy leiding 'n soort statuut geword waaraan die lidmate hulle moes hou.

Met sy kerklike kongres in Amsterdam gedurende 1887 moes iedereen wat die kongres wou bywoon eers 'n "akkoord van kerklike gemeenskap" onderteken, 'n soort kontrak wat instemming vooraf betuig. Hierdie "juridiese belydenis" is deur dr Hoedemaker genoem "'n hart op versterk water."1 Op hierdie wyse word van die belydenis iets onafhankliks van die kerk gemaak in stryd met Art. 7 van die Nederlandse Geloofsbelydenis, volgens Hoedemaker.

Met die Doleansie in sig, is die kerklike kongres daargestel met die "akkoord" as teken van instemming. "Maar het geeft niets. Men snydt hiermee alleen af wat krank is, maar daarom nog niet ongeneeslik was." 2 
Hierdie siening ten opsigte van die belydenis het dit vanself meegebring dat op die kerk van die Doleansie, die Gereformeerde Kerke, die naam van Belydeniskerk toegepas is, en wel omdat die kerke by "aanvang en voortduring zich op de belydenis hebben beroepen." ${ }^{3}$

Hoedemaker stel keer op keer sy ideaal van 'n Christusbelydende volkskerk teenoor die belydeniskerk van dr Kuyper. "Wy verwachten heil, niet van een formule, maar van de kerk, die belydt; niet heeft beleden, niet een rechtsgeldende belydenis bezit, maar belydt." ${ }^{4}$

Die groot invloed van dr Kuyper het tot in Suid-Afrika gestrek. Ook hier het sy leringe wortel geskied. Wat die Gereformeerde Kerk betref, is dit bewerkstellig veral deur prof dr J D du Toit en prof dr F Postma, albei leerlinge van dr Kuyper aan die Vrye Universiteit in Amsterdam. Onder hulle leiding en dié van ander predikante wat ook aan die Vrye Universiteit gestudeer het, het die Gereformeerde Kerk in Suid-Afrika geleidelik al meer afgeswenk van die standpunte van die Christelik Geref Kerk in Nederland wat deur ds D Postma hierheen gebring is, en oorgeskakel na die teologiese leiding van $\mathrm{dr}$ Kuyper.

Maar dit wil nie sê dat al die implikasies van die neo-calvinisme van Kuyper "huid en haar" oorgeneem is deur die Gereformeerde Kerk nie. As voorbeeld hiervan verwys ons na die vraagstuk belydeniskerk of belydende kerk. Hoewel die Gereformeerde Kerk die belydenis beklemtoon en Skrif en belydenis so min of meer langs mekaar stel net asof hulle op dieselfde vlak sou staan, moet tog erken word dat sover by ons bekend die Gereformeerdes nie van hulle kerk spreek as belydeniskerk nie.

Wat die Nederduitsch Gereformeerde Kerk betref, is dit anders. Met die oorname van die Kaap deur Engeland het ook die kerklike bande met Nederland verslap. Veral onder die invloed van die Engelse goewerneurs soos Somerset en Sir Harry Smith het daar 'n Engelse stroming in die Kaapse Kerk sy invloed laat geld en is Skotse predikante beroep vir die Afrikaanse gemeentes. Dit het meegebring dat die studente uit die Kaap wat tevore in Utrecht in Nederland hulle opleiding ontvang het, na Edenburg in Skotland vir die doel gegaan het. Op dié wyse het die Metodisme 'n staanplek in die Nederduitsch Gereformeerde Kerk gekry.

Met die oplewing van die Gereformeerde leer onder die dinamiese leiding van dr Kuyper het die Vrye Universiteit in Amsterdam veld gewen op Edenburg en Suid-Afrikaanse studente uit Stellenbosch getrek wat na die buiteland wou gaan vir verdere studie. Van dié manne wat aan die Vrye Universiteit gestudeer het en die invloed van die groot Kuyper ondergaan het, is later aangestel as professore sowel in Stellenbosch, asook in Pretoria by die teologiese Afdeling B aan die universiteit aldaar.

Hierdie manne het die neo-calvinistiese idees van dr Kuyper in 
die Suid-Afrikaanse teologiese wêreld oorgedra, ook as 'n teenvoeter teen die Metodisme. En as gevolg van Kuyperiaanse beïnvloeding verwerp hulle die gedagte aan 'n Christusbelydende volkskerk en stel as hulle standpunt die belydeniskerk. ${ }^{5}$ Onlangs nog het ds Beukes, die voorlaaste moderator van die Algemene Sinode van die Nederduitsch Gereformeerde Kerk, nog weer dit bevestig: "Ons is mos 'n belydeniskerk."

'n Verdere oordra van die teologiese idees van dr Kuyper in die Kaapse Nederduitsch Gereformeerde Kerk kan ook gesien word in die verandering, a la dr Kuyper se standpunt oor Art 36 van die Nederlandse Geloofsbelydenis, wat deur die sinode van die Kaapse Nederduitsch Gereformeerde Kerk aanvaar is, ${ }^{7}$ en dit sonder die medewerking van die Nederduitsch Gereformeerde Kerke in die ander provinsies.

Ook volgens wyle prof B B Keet is alle Gereformeerde Kerke belydeniskerke. $^{8}$

Hierteenoor staan manne van konfessionele oortuiging in Nederlandse Hervormde Kerke soos prof van Niftrik en dr J Ch Kromsigt wat niks wil weet van die Kuyperiaanse standpunt van 'n belydeniskerk nie, maar die idee van 'n belydende kerk onderskrywe. Van Niftrik stel dit so:

"De Kerk zy belydend. Echter dan ook niet: 'haar geloof' belydend, wat de inhoud van dat geloof dan ook moge zyn met terzyde stelling der belydenisschriften"...

"Ook niet: de Kerk zy belydend met reducering der belydenis tot een grootste gemene deler van richtingovertuigingen. Neen, ze zy belydend met handhaving van de inhoud van haar belydenisgeschriften, waarby echter in haar wettige meerdere vergaderngen by opgekomen beswaren gelegenheid bestaat zich van die belydenis te beroepen op Gods Woord."

En dan stel hy dit treffend soos volg:

"Van hoe groot gewicht de belydenis als woord der Kerk ook moge zyn, hoofdaad in de Kerk is niet haar woord maar het Woord van God. Niet het belydenisgeschrift maar de Heilige Schrift ligt geopend op haar kansels. Daaraan komt alleen volstrekte zeggenschap, absoluut gezag toe over's Heren Kerk ... Het heeft voor de Kerk niet meer maar ook niet minder dan betrekkelyke, geen volstrekte waarde en dan ook alleen, waar het in levende betrekking staat tot Gods Woord, en de betrekking door de belydende Kerk in het beroep op dat Woord gestadig word onderhouden ... Op deze wyse functionerend in de wettige vergaderingen der Kerk is de belydenis als een hart in het levende lichaam. Op zichzelf gesteld buiten dat lichaam opgeborgen als in en safe ... is ze gelyk Hoedemaker zeide: als een hart op sterk water. Dan versterft, versteent ze en werkt verstenend." 
Hierby aansluitend stel dr J Ch Kromsigt dit so: "Wy willen geen belydenislooze kerk... Ook willen wy geen belydeniskerk ... Wat willen we dan?

Een belydende Kerk? Ja, maar mens verstaan ons dan wel. Geen kerk die haar geloof belydt zoo zonder meer. Maar een kerk die dan Christus Gods naar de Schriften belydt. Met het oog op den enkelen geloovige zegt Jesus, Matth 10:32 - niet: 'Die belyden zal' - maar 'Die My belyden zal voor de menschen, dien zal Ik ook belyden voor mynen Vader, die in de hemelen is." ${ }^{10}$

Die belydenis van die kerk is inderdaad van groot belang, omdat die kerk daarmee sê wat hy bely, maar van die allergrootste belang is dit nie en dit is so, omdat elke belydenis die stempel van sy tyd dra en omdat dit ' $n$ menslike grondslag het al is daardie grondslag ook nog so uitstekend. Tog kan 'n kerk nie sonder belydenis wees nie, want as ' $n$ kerk sy Heer en Verlosser nie bely nie, dan het so 'n kerk belydenisloos geword en as sodanig die enigste Naam wat onder die hemel gegee is waardeur die mens gered kan word, verloën. ${ }^{11}$

Maar tog moet daarop gewys word, dat die kerk nie sy belydenis bely nie en daarom geen belydeniskerk is nie, maar wel 'n belydende kerk is, wat sy Heer en Verlosser bely, naamlik die gekruisigde en opgewekte Here. So stel Paulus dit ook: "Ons verkondig Christus, wat gekruisig is." 12

As Jesus aan sy dissipels vra: "Wie sê julle is Ek, dan bely Petrus nie sy belydenis nie, maar dan antwoord hy: $U$ is die Christus, die Seun van die lewende God." ${ }^{13}$ Die vaste fondament var: die kerk is Jesus Christus, sy Persoon, sy versoening, sy bevrydende Woord.

En omdat die kerk nie gegrond is op sy belydenis nie, maar op Christus, sy Heer, daarom is die kerk, al het hy ook, en al moet hy ook ' $n$ belydenis hê, nie ' $n$ belydeniskerk nie, maar wel ' $n$ belydende kerk.

By 'n belydeniskerk is die gevaar groot dat die belydenis té hoog geskat word, en uiteindelik op dieselfde vlak gestel word as die Heilige Skrif. Skrif en belydenis word dan langs mekaar gestel in plaas van dat die belydenis onder die Heilige Skrif gestel word.

Samevattend sou ons dit so kan stel: Die Kerk is 'n belydende kerk, wat Christus, sy Hoof en Heer bely en vir daardie doel gebruik maak van sy belydenis.

\section{FOETNOTAS}

1 Een Onbegrepen Denker, bl 90 en Wie was dr Hoedemaker? deur dr P J Kromsigt, bl 15.

2 Een Onbegrepen Denker, bl 91.

3 Dr P J Kromsigt in Hervormd Weekblad De Gereformeerde Kerk, 471935.

4 De Gereformeerde Kerk, Jaargang 1895 nr 340. 
5 Die Voorligter, Julie 1954 en prof F I M Potgieter in Die Transvaler, 12 Oktober 1965.

6 Die Kerkbode.

7 Die Kerkbode - 19 Oktober 1960, bl 536.

8 Die Kerkbode - 17 Desember 1941, bl 1017.

9 De Gereformeerde Kerk, bl 409.

10 Hervormd Weekblad, De Gereformeerde Kerk 3 Maart 1938, bl 186.

11 Hand 4:12

121 Kor 1:23

13 Mat 16:16 